\title{
The Nature of Mother's Employment on Nurturing Campus Persistence among Undergraduate Students
}

\author{
Vijayalakshmi N. S. ${ }^{1} \&$ A. H. Sequeira ${ }^{1}$ \\ ${ }^{1}$ School of Management, National Institute of Technology Karnataka, Surathkal, Mangalore, India \\ Correspondence: Vijayalakshmi N. S., School of Management, National Institute of Technology Karnataka, \\ Surathkal, Mangalore, India. E-mail: vijaylakshmins@nitk.edu.in; nandalike17@gmail.com
}

Received: January 26, 2017

Accepted: February 14, $2017 \quad$ Online Published: May 31, 2017

doi:10.5539/ass.v13n6p36

URL: https://doi.org/10.5539/ass.v13n6p36

\begin{abstract}
Objective: The study aims to empirically test the relationship between types of campus adaptations across students' mothers' level of nature of occupation among engineering undergraduate B. Tech students pursuing a four-year study at Indian Institutes of Technology (IIT's) and National Institutes of Technology (NIT's) in India.

Method: The Multivariate Analysis of Variance (Manova) test was run with SPSS vs. 21 to compare the student's campus adaptations of IIT's and NIT's by students' mothers' level of occupation. Multistage random sampling with $n=1420$ students were selected comprising of employed at government $(n=172)$, employed at private $(n=141)$, own a business $(n=71)$ employed as unskilled labourer $(n=10)$, farmer $(n=10)$, retired from government service or pensioner $(n=06)$, not alive $(n=03)$, unemployed $(n=107)$.

Result: In the academic adaptation, students' mothers' who were employed by the government, owned a business, employed as unskilled labourer and pursued farming had positive outcome while students' whose mothers' were employed at private, retired from government service, not alive and unemployed had negative outcomes. In social adaptation students' whose mothers' were employed by the government, owned a business, retired from government service and unemployed had positive outcomes while students' whose mothers' were employed at private, employed as an unskilled labourer, pursued farming and not alive had negative outcomes. In physical psychological adaptation, students' mothers' who owned a business, not alive and unemployed had positive outcomes while student's mothers' employed at the government, employed at private, employed as an unskilled labourer, pursued farming and retired from government service had negative outcomes. In the institutional adaptation, students' mothers' employed at the government, employed at private own a business, employed as an unskilled labourer, retired from government service and not alive had positive outcomes and students whose mothers' were farmers and unemployed had negative outcomes.
\end{abstract}

Conclusion: Campus adaptations do vary across student's mother's level of occupation influencing student's experiences at IIT's and NIT's.

Keywords: socio-economic status, parents, mother, occupation, adaptation

\section{Introduction}

Parents' expectations and socio-cultural background influences overall adjustment and academic achievement of students (Balboni \& Pedrabissi, 1998). Mothers' and mothers' attitudes differed toward their children's academic performance and perceptions of academic competence by gender (McGrath \& Repetti, 2000). The socio-economic problems impact transition from knowledge-based economy to knowledge-based society (Mindeli \& Pipiya, 2007) where socioeconomic differences in family size reflect cultural differences in confidence and social support for parenting (Newman, 2009). This reflects that social background differences in education and youth transitions in higher education (Iannelli \& Smyth, 2008) impacts transitions to post-secondary and tertiary education (Tieben \& Wolbers, 2010). The parent's academic involvement impacts students perceptions of achievement goals (Régner, Loose, \& Dumas, 2009) with social and economic purposes of higher purposes of higher education (McArthur, 2011a). Ball and Vincent's concepts of 'hot' (informal) and 'cold' (formal) knowledge provide a complimentary resource for exploring students from low socio-economic status access knowledge (L. Smith, 2011). Though culture and economic factors are found to influence students decision towards higher education (Bowden \& Doughney, 2012); parents' concerns exist over the inclusion of 
engineering education by its concepts of learning to lower levels of education (Kluin, 2012). Further engineering diversity can be enhanced by the inclusion of students from low socio-economic status into engineering (Lundy-wagner, 2013). In short, socio-economic status diversifies in higher education (Ahmar \& Anwar, 2013) where parents vary by their profound influence college planning process (Hallett \& Griffen, 2015) which has predictive effects of parental involvement on academic achievement (Veas, Gilar, \& Miñano, 2016).

Parents Occupation: Maternal occupation influences college students by gender (Weer, Greenhaus, Colakoglu, \& Foley, 2006) where mothers' full-time employment is found to vary self-efficacy of students' of a minority race (Buchanan \& Selmon, 2008). Parental employment affect children's educational attainment (Schildberg Hoerisch, 2011) with effectiveness of developing pathways to university entry for low socio-economic status of students' varies (Sydney, 2011)

The study seeks to analyse the relationship among mother's level of education on campus adaptations of students with the following research question and research objective

Research Question: - What makes campus adaptations of academic, social, physical - psychological and institutional attachment unique across mother's level of nature of occupation?

Research Objectives: - To examine the existence of variance among campus adaptations of academic, social, physical psychological and institutional across mother's level of nature of the occupation.

\section{Campus Adaptation}

\subsection{Academic Adaptation}

Parents and career counseling centers have an impact on career orientations of students' (Salami, 2004). Parents especially mother' influenced girl's academic major choice of information technology (Adya \& Kaiser, 2005) while the mothers' influence is yet to be known or discovered. Higher education needs to relocate itself with directions for change in the enhancement of experience on campus socio-economic status by women faculty in academics (Sheridan, Brennan, Carnes, \& Handelsman, 2006). With social class often known to be impacting academic engagement (Kelly, 2008); the socio economic status is known leave its essentiality on learning ability and subsequent placement of students in the undergraduate study (Dar \& Getz, 2007). The parental influence on work and family plans of adolescents diversifies by ethnic backgrounds (De Valk, 2008) where internet use for academic purpose is also found to be low among students with low socio-economic status (Aerschot \& Rodousakis, 2008) with frequency of its use also varying by socio-economic status (Koc \& Tamer, 2011). Thus there is an intergenerational link in educational attainment where family background and student characteristics impact academic achievement level of students (Pettit, Yu, Dodge, \& Bates, 2009). Family systems predict career attitude maturity among students (S. K. Lee \& Yi, 2010) where parents impact the development of gender attitudes on academic majors (Gunderson, Ramirez, Levine, \& Beilock, 2012) and socio-economic status impacts scholastic achievement in students (Chaliha \& Hazarika, 2012). In brief, parents support impacts learning goal orientation and career decision-making self-efficacy among students (Garcia, Restubog, Toledano, Tolentino, \& Rafferty, 2012a) but parents and teacher's perceptions of information communication technology professionals vary by gender impacting students' academic major choice (Sáinz, Pálmen, \& García-Cuesta, 2012). Therefore, parenting style impacted academic procrastination (Zakeri, Esfahani, \& Razmjoee, 2013) where it is known that inter-parental conflict impact academic adjustment of first year students (Parsa, Panah, Parsa, \& Ghaleiha, 2014) and socio-economic status influencing students' academic performance (Flor et al., 2015). However, though mother level of influence on academic achievement in high school students is intrigued (Marissa \& Ishaaq, 2012); the mothers' level of influence by employment on her child's academics is still let unknown.

\subsection{Social Adaptation}

Family structure impacts women's education and works (Eapen \& Kodoth, 2002) as it is family obligations that impact young women's transition to college (Sy \& Brittian, 2008). Urban learning with the bandwagon of family background affects academic achievement (Geske, Grinfelds, \& Dedze, 2003). Further communication with parents has its imprint on the adjustment of students (Agliata \& Renk, 2008). Parents' educational goals differ by race impacting academic achievement (Chang et al., 2010). Thus the incidence of structural factors like leaving parental home as a transition to adulthood (A. Moreno, 2012) makes students travel or mobility essential (Shokoohi, Hanif, \& Dali, 2012) towards distant places of higher learning institutions. Moreover, parental bonding promotes parental-child relationships essentially leaving its footprints on students' academics (Lian, 2008). In brief, gender norms and institutional culture which are found to influences socialisation of college students with family friendly vs motherly friendly institution (Sallee, 2013) being the only child in the family too 
remains frisky from socialising perspective at campuses (Chu, Khan, Jahn, \& Kraemer, 2015).

\subsection{Physical - Psychological Adaptation}

\subsubsection{Physical Adaptation}

Health-related risk factors like obesity is higher among low socio-economic students (Y. Wang et al., 2007) indicating that family support to weight loss strategies among adolescents impacts health (Utter, Denny, Dixon, Ameratunga, \& Teevale, 2012).

\subsubsection{Psychological Adaptation}

Family background with family composition and emotional atmosphere impacts students' academic performance (Onatsu-Arvilommi \& Nurmi, 1997) even to that of career planning especially of a disadvantaged group (Arulmani, Laar, Easton, \& Simon, 2001). Further parenting type influences social adjustment and psychological well-being of students (Domitrovich \& Bierman, 2001) bearing its fringe on individual self-esteem towards college adjustment (Lipschitz-Elhawi \& Itzhaky, 2005). Parent relationships, emotion regulation, psychosocial maturity makes a bearing on student's addiction types like alcohol use (J. L. Fischer, Forthun, Pidcock, \& Dowd, 2007) essentially calling on the need for disciplinary action on college students (B. Smith, Ray, Stefurak, \& Zachar, 2007) as it is parental child-rearing strategies that influence self-regulation, socio-emotional adjustment, and psychopathology in early adulthood (Baker \& Hoerger, 2012). The social background and parental involvement is also said to have early ethnic inequality on cognitive development among students of a minority race (Biedinger, 2010). The socio-economic status with gender trolls on the academic self-concept of students (Low \& Ishak, 2012) with family socio-economic status predicting self-efficacy of students (Mazur, Malkowska-Szkutnik, \& Tabak, 2014) that could influence the emotional stability of students (Kumar, 2013). In short, emotional intelligence impacts work family conflict of university students (Panorama \& Jdaitawi, 2011) with self-confidence backed up by family background rever on economic outcomes (Filippin \& Paccagnella, 2012). Lastly, Kinship social support was positively associated with mother's optimism and negatively associated with their depressive symptoms (Taylor, 2015).

\subsection{Institution Adaptation}

Socioeconomic status influences predictability of college performance (Wright, Bean, Journal, \& Winter, 2014) as it is often noticed that students from high socio-economic status attended prestigious college or institutions had a positive bearing on time management and skills (C. W. H. a Kim \& Dembo, 2001). The selectivity of the institute, however, relied on ethnicity, gender and socio-economic status (Frederickson \& Petrides, 2008) where parental influence in the choice of students persisted (Bekerman \& Tatar, 2009). Thus social class (Misran et al., 2012) and socio-economic status impacts campus life in highly selective elite institutions (Martin, 2012) with predominance on overall institutional performance (Teodor, 2012)

The study proposes the following research hypothesis: -

$\mathrm{H}_{0}$ : - Campus adaptations of academic, social, physical - psychological and institutional environments do not vary among undergraduate students by their mother's level of nature of occupation

$\mathrm{H}_{1}$ : - There is a significant difference in campus adaptations of academic, social, physical - psychological and institutional adaptations impacted by undergraduate student's mother's level of occupation attained.

\section{Methods}

\subsection{Participant}

The reference populations were undergraduate 4-year B. tech students enrolled on a regular study mode at IIT's and NIT's. A total of 1460 students' participated with 1420 of valid responses for an overall 97.26 percent participation rate after deducting the questionnaire that contained empty answers. Data was collected for 20 weeks across institutions of IIT's and NIT's. Of the 1420 undergraduate respondents on students' mothers' $12.11 \%$ were employed in government sector, $9.92 \%$ were employed at private sector, $5 \%$ owned a business $0.70 \%$ employed as unskilled labourer, $0.70 \%$ as farmers, $0.42 \%$ as pensioners retired from service and unfortunately, $0.21 \%$ students' mothers' were not alive. Lastly, $7.53 \%$ were unemployed or made better homemakers only.

\subsection{Sampling}

Probability sampling technique followed by cluster sampling in the identification of institutes of IIT's and NIT's was adopted. This is followed up with stratified sampling in sample choice of undergraduate students' population and simple random in collecting data from the chosen student population stated above. 


\subsection{Instrument and Procedure}

The survey was conducted using a structured online questionnaire with reference to student's campus and non campus email accounts. At all times, the students were informed of the anonymous, confidential, and voluntary nature of their participation and any doubts that arose were clarified.

\subsection{Measures}

All the 21 items in the questionnaire were measured with the rating on a five-point likert scale ranging from " $1=$ strongly disagree" to " $5=$ strongly Agree". Reliability and validity of the questionnaire was tested

\section{Data Analysis}

Multivariate analyses of variance (MANOVA) were conducted to assess' occupational group differences in campus adaptation. This was followed by discriminant analysis to determine the nature of the effect of campus adaptations by each mother's occupational group. There are several assumptions behind an MANOVA, including multivariate normality, the linearity of relationships, the low influence of univariate and multivariate outliers, homogeneity of variance- covariance matrices and an absence of multicollinearity. Each assumption was tested, and no serious violations were noted.

Table 1. Pearson Correlation

\begin{tabular}{ccccccc}
\hline Campus Adaptation & 1 & 2 & 3 & 4 & $\mathrm{M}$ & SD \\
\hline 1.Academic Adaptation & 1.00 & & & & 2.60 & 0.702 \\
2.Social Adaptation & 0.579 & 1.00 & & & 2.72 & 0.755 \\
3.Physical - Psychological Adaptation & 0.523 & 0.576 & 1.00 & & 2.28 & 0.771 \\
4.Institutional Adaptation & 0.576 & 0.617 & 0.790 & 1.00 & 2.14 & 0.784 \\
\hline
\end{tabular}

Note: $\mathrm{n}=1420$.Correlations greater than 0.05 are statistically significant

\subsection{Descriptive Statistics}

Table 2. Distribution of difference in dimensions of campus adaptations

\begin{tabular}{|c|c|c|c|c|c|c|c|c|}
\hline \multirow{2}{*}{ Mother's Level of Employment } & \multicolumn{2}{|c|}{ Academic } & \multicolumn{2}{|c|}{ Social } & \multicolumn{2}{|c|}{$\begin{array}{c}\text { Physical - } \\
\text { Psychological }\end{array}$} & \multicolumn{2}{|c|}{ Institutional } \\
\hline & Mean & $\begin{array}{l}\text { Std. } \\
\text { Dev }\end{array}$ & Mean & $\begin{array}{l}\text { Std. } \\
\text { Dev }\end{array}$ & Mean & Std. Dev & Mean & $\begin{array}{l}\text { Std. } \\
\text { Dev }\end{array}$ \\
\hline Employed at Government $(\mathrm{n}=172)$ & 2.60 & 0.688 & 2.83 & 0.724 & 2.28 & 0.745 & 2.12 & 0.738 \\
\hline Employed at Private $(\mathrm{n}=141)$ & 2.49 & 0.676 & 2.63 & 0.745 & 2.26 & 0.773 & 2.12 & 0.763 \\
\hline Own a Business $(\mathrm{n}=71)$ & 2.67 & 0.685 & 2.79 & 0.790 & 2.38 & 0.789 & 2.22 & 0.793 \\
\hline Employed as unskilled Labourer $(\mathrm{n}=10)$ & 2.50 & 0.922 & 2.82 & 0.990 & 2.26 & 1.011 & 2.18 & 0.968 \\
\hline Farmer $(n=10)$ & 2.24 & 0.600 & 2.60 & 0.884 & 2.04 & 0.798 & 1.90 & 0.731 \\
\hline $\begin{array}{l}\text { Retired from Government service or } \\
\text { Pensioner }(\mathrm{n}=6)\end{array}$ & 2.94 & 1.118 & 2.43 & 0.674 & 1.86 & 0.413 & 2.13 & 0.776 \\
\hline Not Alive $(\mathrm{n}=3)$ & 2.50 & 0.440 & 2.40 & 0.721 & 2.40 & 0.692 & 2.33 & 0.808 \\
\hline Unemployed $(\mathrm{n}=107)$ & 2.61 & 0.705 & 2.71 & 0.755 & 2.28 & 0.774 & 2.14 & 0.795 \\
\hline Total $(n=1420)$ & 2.60 & 0.702 & 2.72 & 0.755 & 2.28 & 0.771 & 2.14 & 0.784 \\
\hline
\end{tabular}

The mean in the descriptive statistics indicate that among undergraduate B.Tech students, students enjoyed high level of social adaptation irrespective mothers' occupation, with mothers' employed at government $(\mathrm{M}=2.83$, $\mathrm{SD}=0.724)$ employed at private $(\mathrm{M}=2.63, \mathrm{SD}=0.745)$ own a business $(\mathrm{M}=2.79, \mathrm{SD}=0.790)$ unskilled labourer $(\mathrm{M}=2.82, \mathrm{SD}=0.990)$ farmer $(\mathrm{M}=2.60, \mathrm{SD}=0.884)$ unemployed $(\mathrm{M}=2.71, \mathrm{SD}=0.755)$ with exception to parents employed retired had high level of academic adaptation $(\mathrm{M}=2.94, \mathrm{SD}=1.118)$ and not 
alive $(\mathrm{M}=2.50 \mathrm{SD}=0.440)$.

However, mother's occupation level across occupations had lower level of institutional adaptation with mother being employed at government $(\mathrm{M}=2.12, \mathrm{SD}=0.738)$ employed at private $(\mathrm{M}=2.12, \mathrm{SD}=0.763)$ own a business $(\mathrm{M}=2.22, \mathrm{SD}=0.793)$ unskilled labourer $(\mathrm{M}=2.18, \mathrm{SD}=0.968)$ farmer $(\mathrm{M}=1.90, \mathrm{SD}=0.731)$ not alive $(\mathrm{M}=2.33, \mathrm{SD}=0.808)$ and unemployed $(\mathrm{M}=2.14, \mathrm{SD}=0.795)$. The exception being retired mother where students witnessed lowest level of Physical - psychological adaptation where $(\mathrm{M}=1.86, \mathrm{SD}=0.413)$

Further within Academic Adaptation students whose mothers' owned a business had high level of impact on adaptation $(\mathrm{M}=2.67, \mathrm{SD}=0.685)$ and students whose mothers' were farmers had low level of adaptation $(\mathrm{M}=$ $2.24, \mathrm{SD}=0.600)$

In Social Adaptation, who were employed at government had high level of impact on adaptation $(\mathrm{M}=2.83, \mathrm{SD}=$ $0.724)$ and students whose mothers' were not alive impacted in low level of adaptation $(M=2.40, S D=0.721)$

In Physical - Psychological adaptation, students whose mother owned a business had high impact on level of adaptation $(\mathrm{M}=2.38, \mathrm{SD}=0.789)$ and students whose mother were retired impacted in low level of adaptation $(\mathrm{M}=1.86, \mathrm{SD}=0.413)$

In Institutional adaptation, students whose parents were not alive had high impact on student's level of adaptation $(\mathrm{M}=2.33, \mathrm{SD}=0.808)$ and students whose mothers were farmers impacted on student's low level of adaptation $(\mathrm{M}=1.90, \mathrm{SD}=0.731)$

Overall, across campus adaptations and mothers' educational level groups, students had high level of social adaptation $(\mathrm{M}=2.72, \mathrm{SD}=0.755)$ and low level of Institutional adaptation $(\mathrm{M}=2.14, \mathrm{SD}=0.784)$. However, within mother's occupation level, parent mother' who was employed at government had high level of impact on student's social adaptation $(\mathrm{M}=2.83, \mathrm{SD}=0.724)$ and students whose mother was a farmer had low level of institutional adaptation $(\mathrm{M}=1.90, \mathrm{SD}=0.731)$

\subsection{Inferential Statistics}

The Box's M value of 57.426 indicates a test of assumption of equality of covariance matrices are roughly equal as assumed with $p=0.814(\mathrm{p}>0.001)$.

Using Manova test statistic of Pillai's Trace, there was a non-significant effect of mother's occupation on students' Academic, Social, Physical - Psychological and Institutional campus adaptations ( $\mathrm{V}=0.022, F(28$, $5648)=1.121$ and $p=0.301) *(p>0.05)$.

Using Manova test statistic of Wilks Lambda, there was a non-significant effect of mother's occupation on students' Academic, Social, Physical - Psychological and Institutional campus adaptations $(\Lambda=0.978, F(28$, $5081)=1.121$ and $p=0.301) *(p>0.05)$.

Using Manova test statistic of Hotelling's trace, there was a non significant effect of mother's occupation on student's campus adaptations of Academic, Social, Physical - Psychological and Institutional ( $\mathrm{T}=0.022, F(28$, $5630)=1.121$ and $p=0.301) *(p>0.05)$.

Using Manova test statistic of Roy's largest root, there was a significant effect of mother's occupation on student's campus adaptations of Academic, Social, Physical - Psychological and Institutional $(\Theta=0.012$, F $(7,1412)=2.330$ and $p=0.023) *(p<0.05)$.

The univariate test statistic with Levene's test of equality of variances for each of the dependent variable is non-significant i,e $\mathrm{p}>0.05$ with an academic adaptation of 0.312 , social adaptation of 0.827 , physical psychological adaptation of 0.839 and institutional adaptation of 0.964 enabling the assumptions of homogeneity of variance being met.

However separate univariate analysis or ANOVA on the outcome with F $(7,1412)$ for Academic, social, Physical - Psychological and institutional adaptation revealed a non - significant effect with F value (1.203) (1.231) $(0.609)$ and $(0.302)$ with p-value (0.298) (0.282) (0.749) and (0.953)

Further, the between - subjects SSCP matrix indicates that the sum of squares for the error SSCP matrix are substantially bigger than in the model (or mother's occupation) SSCP matrix, whereas absolute values of cross products are fairly similar. This pattern of relationship indicates that the relationship between dependent variables is significant than individual dependent variables themselves. Thus to determine the nature of the effect of mother's employment among dependent variables Manova is followed with discriminant analysis.

The first discriminant function explained $51.8 \%$ of the variance with canonical $\mathrm{R}^{2}=0.012$; the second discriminant function explained $31.7 \%$ of the variance with canonical $\mathrm{R}^{2}=0.007$; the third discriminant function 
explained $14.3 \%$ of the variance with canonical $\mathrm{R}^{2}=0.003$; the fourth discriminant function explained $2.2 \%$ of the variance with canonical $\mathrm{R}^{2}=0.000$ indicates that the variance in the canonical derived dependent variable was associated with mother's level of occupation.

In combination these discriminant functions did not significantly discriminate the mother's occupation level with the first discriminant function $\Lambda=0.978, \mathrm{x}^{2}(28) 31.361, \mathrm{p}=0.301(p>0.05)$; The second discriminant function $\Lambda=0.989, \mathrm{x}^{2}(18) 15.135, \mathrm{p}=0.653(p>0.05)$; The third discriminant function $\Lambda=0.996, \mathrm{x}^{2}$ (10) $5.173, \mathrm{p}=$ $0.879(p>0.05)$ and the fourth discriminate function $\Lambda=1.000, \mathrm{x}^{2}$ (4) $0.682, \mathrm{p}=0.954(p>0.05)$. indicates the non-significant effect of discriminant functions.

The correlations between outcomes and the discriminant functions revealed that social adaptation loaded highly on first function $(\mathrm{r}=0.561)$ indicating it contributed more to the mother's occupation level group separation (Bragman, 1970) than the relatively fair high loading in positive relationship in second function $(\mathrm{r}=0.533)$ third function (0.309) and fourth function $(\mathrm{r}=0.552)$

Academic adaptation loaded highly on second function $(r=0.797)$ indicating it contributed more to the mother's occupation level group separation than the relatively high loading in positive relationship with third function $(\mathrm{r}=$ $0.507)$ and fourth function $(r=0.232)$ negated by negative relationship in the fourth function $(r=-0.234)$;

Physical - psychological adaptation loaded highly on third function with $(r=0.919)$ indicating it contributed more to the mother's occupation level group separation than the than relatively fair high loading in the first function $(\mathrm{r}=0.152)$ second function $(\mathrm{r}=0.011)$ and fourth function $(\mathrm{r}=0.365)$

Lastly, institutional adaptation loaded highly on fourth function with $(r=0.882)$ indicating it contributed more to the mother's occupation level group separation than the relatively fair high loading in positive relationship with second function $(\mathrm{r}=0.101)$ and third function $(\mathrm{r}=0.550)$ with negative relationship in the first function $(\mathrm{r}=-$ $0.109)$

\subsection{Findings}

The mother's occupation of being employed at government had positive academic (0.198) social (0.088) and institutional (0.009) adaptation with negative outcomes in physical - psychological (-0.041) adaptation.

The mother's occupation of being employed at private had positive outcome at institutional (0.009) adaptation with negative outcomes in academic (-0.036) social (-0.183) and physical - psychological (-0.031) adaptation.

The mother's occupation of owning a business had positive outcomes in academic (0.025) social (0.038) physical - psychological (0.122) and institutional (0.038) adaptation.

The mother's occupation of employed as unskilled labourer had positive outcome in academic (0.203) and institutional (0.186) adaptation with negative outcome in social (-0.084) and physical - psychological (-0.146) adaptation.

The mother's occupation of being son of soil, the farmer had positive outcomes in academic (0.264) adaptation with negative outcomes in social (-0.306) physical - psychological (-0.363) and institutional (-0.066) adaptation

The mother's who are retired and now as government pensioner had positive outcome on students social (0.568) and institutional (0.077) adaptation with negative outcomes in academic (-1.049) and physical - psychological (0.457)

The mother's whose mother had expired had positive physical - psychological (0.192) and institutional (0.152) adaptation with negative outcomes in academic $(-0.536)$ and social $(-0.510)$ adaptations

The students whose mother was unemployed had positive social $(0.010)$ and physical - psychological $(0.010)$ with negative outcomes in academic (-0.027) and institutional (-0.008) adaptation.

Conclusion: - Maternal employment has a significant bearing on the child's campus adaptation. It's the not that just the alternate hand at play for work in the family; but it is the best hand that ensures its efficiency domestically as well as occupational forefront. The support the mother creates for her child in his or her education can never be redundant as she is the only woman by heart and soul who would justify by her presence and other means to help out her child to emerge successfully as a student and better human being at the campus.

Implication: - The study takes a look at mother's perspective alone of being employed and engaged on diverse nature of work on her child's adaptation to college which was earlier very much about parent's employment nature on students at the college. By analysing on a divergence in nature of employment different from a father's perspective who by far remained the major bread winner of the family; the study throws light that a mother's involvement in her nature of employment could have differed impact on student's adaptation at college. A future 
work on comparative nature of employment of parents on the child well-being and satisfaction at college could really add on to the vivid picture that often remains skewed to the gloomy glossy picture that a student is all fine at the campus and student's internal environment alone suffixes his or success.

\section{References}

Adya, M., \& Kaiser, K. M. (2005). Early determinants of women in the IT workforce: a model of girls' career choices. Information Technology \& People, 18(3), 230-259. https://doi.org/10.1108/09593840510615860

Aerschot, L. Van, \& Rodousakis, N. (2008). The link between socio-economic background and Internet use: barriers faced by low socio-economic status groups and possible solutions. Innovation: The European Journal of Social Science Research, 21(4), 317-351. https://doi.org/10.1080/13511610802576927

Agliata, A. K., \& Renk, K. (2008). College students' adjustment: The role of parent-college student expectation discrepancies and communication reciprocity. Journal of Youth and Adolescence, 37(8), 967-982. https://doi.org/10.1007/s10964-007-9200-8

Ahmar, F., \& Anwar, E. (2013). Socio Economic Status and its relation to academic achievement of higher secondary school students. Journal of Humanities and Social Science, 13(6), 13-20.

Arulmani, G., Laar, V., Easton, D. and, \& Simon. (2001). Career planning orientation of disadvantaged high school boys: a study of socioeconomic and social cognitive variables. Journal of the Indian Academy of Applied Psychology, 27(1/2), 7-17.

Baker, C. N., \& Hoerger, M. (2012). Parental child-rearing strategies influence self-regulation, socio-emotional adjustment, and psychopathology in early adulthood: Evidence from a retrospective cohort study. Personality and Individual Differences, 52(7), 800-805. https://doi.org/10.1016/j.paid.2011.12.034

Balboni, G., \& Pedrabissi, L. (1998). School Adjustment and Academic Achievement: Parental Expectations and Socio - cultural Background. Early Child Development and Care, 143(1), 79-93. https://doi.org/10.1080/0300443981430107

Bekerman, Z., \& Tatar, M. (2009). Parental choice of schools and parents' perceptions of multicultural and co existence education: the case of the Israeli Palestinian-Jewish bilingual primary schools. European Early Childhood Education Research Journal, 17(2), 171-185. https://doi.org/10.1080/13502930902951304

Biedinger, N. (2010). Early ethnic inequality: The influence of social background and parental involvement on preschool children's cognitive ability in germany. Child Indicators Research, 3(1), 11-28. https://doi.org/10.1007/s12187-009-9054-6

Bowden, M. P., \& Doughney, J. (2012). The importance of cultural and economic influences behind the decision to attend higher education. Journal of Socio-Economics, 41(1), 95-103. https://doi.org/10.1016/j.socec.2011.10.003

Buchanan, T., \& Selmon, N. (2008). Race and gender differences in self-efficacy: Assessing the role of gender role attitudes and family background. Sex Roles, 58(11-12), 822-836. https://doi.org/10.1007/s11199-008-9389-3

Chaliha, A., \& Hazarika, M. (2012). North Lakhimpur College Scholastic Achievement of the Post-Graduate Students of Dibrugarh University, Assam in relation to Socio-Economic Status. Social Science Researcher, 1(July), 1-10.

Chang, E. S., Heckhausen, J., Greenberger, E., \& Chen, C. (2010). Shared Agency with Parents for Educational Goals: Ethnic Differences and Implications for College Adjustment. Journal of Youth and Adolescence, 39(11), 1293-1304. https://doi.org/10.1007/s10964-009-9488-7

Chu, J. J., Khan, M. H., Jahn, H. J., \& Kraemer, A. (2015). Only-child status in relation to perceived stress and studying-related life satisfaction among university students in China: A comparison with international students. PLoS ONE, 10(12), 1-18. https://doi.org/10.1371/journal.pone.0144947

Dar, Y., \& Getz, S. (2007). Learning ability, socioeconomic status, and student placement for undergraduate studies in Israel. Higher Education, 54(1), 41-60. https://doi.org/10.1007/s10734-006-9045-1

De Valk, H. A. G. (2008). Parental influence on work and family plans of adolescents of different ethnic backgrounds in the Netherlands. Sex Roles, 59(9-10), 738-751. https://doi.org/10.1007/s11199-008-9464-9

Domitrovich, C. E., \& Bierman, K. L. (2001). Parenting Practices and Child Social Adjustment: Multiple Pathways of Influence. Merrill-Palmer Quarterly, 47(2), 235-263. https://doi.org/10.1353/mpq.2001.0010 
Eapen, M., \& Kodoth, P. (2002). Family Structure, Women'S Education and Work: Re-Examining the High Status of Women in Kerala.

Filippin, A., \& Paccagnella, M. (2012). Family background, self-confidence and economic outcomes. Economics of Education Review, 31(5), 824-834. https://doi.org/10.1016/j.econedurev.2012.06.002

Fischer, J. L., Forthun, L. F., Pidcock, B. W., \& Dowd, D. a. (2007). Parent relationships, emotion regulation, psychosocial maturity and college student alcohol use problems. Journal of Youth and Adolescence, 36(7), 912-926. https://doi.org/10.1007/s10964-006-9126-6

Flor, M., Lima, O., Sarmento, D., Agripino, G., Verli, F., Carvalho, S., Marinho, S. (2015). Socioeconomic Profile and Academic Performance of Students on Campus VIII of the State University of Paraíba, Araruna, Brazil, 2013. British Journal of Medicine and Medical Research, 5(7), 903-913. https://doi.org/10.9734/BJMMR/2015/13060

Frederickson, N., \& Petrides, K. V. (2008). Ethnic, gender, and socio-economic group differences in academic performance and secondary school selection: A longitudinal analysis. Learning and Individual Differences, 18(2), 144-151. https://doi.org/10.1016/j.lindif.2005.09.001

Garcia, P. R. J. M., Restubog, S. L. D., Toledano, L. S., Tolentino, L. R., \& Rafferty, A. E. (2012a). Differential Moderating Effects of Student- and Parent-Rated Support in the Relationship Between Learning Goal Orientation and Career Decision-Making Self-Efficacy. Journal of Career Assessment, 20(1), 22-33. https://doi.org/10.1177/1069072711417162

Geske, A., Grinfelds, A., \& Dedze, I. (2003). School Quality and Equity in Central and Eastern Europe Family Background, School Quality and Rural-Urban Disparities in Student Learning Achievement in Latvia. Prospects, XXXVI(4), 419-431.

Gunderson, E. A., Ramirez, G., Levine, S. C., \& Beilock, S. L. (2012). New Directions for Research on the Role of Parents and Teachers in the Development of Gender-Related Math Attitudes: Response to Commentaries. Sex Roles, 66(3-4), 191-196. https://doi.org/10.1007/s11199-011-0100-8

Hallett, R. E., \& Griffen, J. (2015). Empowering Parents in the College-Planning Process: An Action-Inquiry Case Study. Journal of Education for Students Placed at Risk (JESPAR), 20(1-2), 101-119. https://doi.org/10.1080/10824669.2014.984035

Iannelli, C., \& Smyth, E. (2008). Mapping gender and social background differences in education and youth transitions across Europe. Journal of Youth Studies, 11(2), 213-232. https://doi.org/10.1080/13676260701863421

Kelly, S. (2008). Race, social class, and student engagement in middle school English classrooms. Social Science Research, 37(2), 434-448. https://doi.org/10.1016/j.ssresearch.2007.08.003

Kim, C. W. H. a, \& Dembo, M. H. (2001). Social-cognitive factors in uencing success on college entrance exams in South Korea. Social Psychology of Education, (4), 95-115. https://doi.org/10.1023/A:1009659529840

Kluin, J. Y. (2012). AC 2012-4385: Parents' Concerns about the Inclusion of Engineering Education into P-12 Classrooms. In American Society for Engineering Education, 2012 (pp. 1-17).

Koc, M., \& Tamer, S. L. (2011). The investigation of Turkish high school students' Internet use profiles across their demographics. Procedia - Social and Behavioral Sciences, 15, 2912-2916. https://doi.org/10.1016/j.sbspro.2011.04.213

Kumar, P. (2013). A Study of Emotional Stability and Socio-Economic. International Journal of Education and Information Studies, 3(1), 7-11.

Lee, S. K., \& Yi, H. S. (2010). Family systems as predictors of career attitude maturity for Korean high school students. Asia Pacific Education Review, 11(2), 141-150. https://doi.org/10.1007/s12564-009-9054-8

Leppel, K., Williams, M. L., \& Waldauer, C. (2001). The impact of parental occupation and socioeconomic status on choice of college major. Journal of Family and Economic, 22(4), 373-394. https://doi.org/10.1023/A:1012716828901

Lian, T. C. (2008). Parental Bonding and Parent-Child Relationship Among Tertiary Students. Sunway Academic Journal, 5(5), 111-127.

Lipschitz-Elhawi, R., \& Itzhaky, H. (2005). Social support, mastery, self-esteem and individual adjustment among at-risk youth. Child and Youth Care Forum, 34(5), 329-346. https://doi.org/10.1007/s10566-005-3 
Low, S. F., \& Ishak, Z. (2012). A Priori Model of Students' Academic Achievement: The Effect of Gender as Moderator. Procedia - Social and Behavioral Sciences, 65(0), 1092-1100. https://doi.org/http://dx.doi.org/10.1016/j.sbspro.2013.02.122

Lundy-wagner, V. C. (2013). Reimagining engineering diversity: A study of academic advisors' perspectives on socioeconomic status Reimagining engineering diversity: A study of institutional. In 120th ASEE Annual conference and Exposition (pp. 1-10).

Marissa, A., \& Ishaaq, F. I. (2012). The Correlation of Perception on the Role of Mother with Academic Achievement in Senior High School Student. Procedia - Social and Behavioral Sciences, 69(Iceepsy), 1369-1373. https://doi.org/10.1016/j.sbspro.2012.12.074

Martin, N. D. (2012). The Privilege of Ease: Social Class and Campus Life at Highly Selective, Private Universities. Research in Higher Education, 53(4), 426-452. https://doi.org/10.1007/s11162-011-9234-3

Mazur, J., Malkowska-Szkutnik, A., \& Tabak, I. (2014). Changes in family socio-economic status as predictors of self-efficacy in 13-year-old Polish adolescents. International Journal of Public Health, 59(1), 107-115. https://doi.org/10.1007/s00038-013-0458-1

McArthur, J. (2011a). Reconsidering the social and economic purposes of higher education. Higher Education Research \& Development, 30(6), 737-749. https://doi.org/10.1080/07294360.2010.539596

McGrath, E. P., \& Repetti, R. L. (2000). Mothers' and Mothers' Attitudes Toward Their Children's Academic Performance and Children's Perceptions of Their Academic Competenece. Journal of Youth and Adolescence, 29(6), 713-723. https://doi.org/10.1023/A:1026460007421

Mindeli, L. E., \& Pipiya, L. K. (2007). Conceptual aspects of formation of a knowledge-based economy. Studies on Russian Economic Development, 18(3), 314-327. https://doi.org/10.1134/S1075700707030100

Misran, N., Sahuri, S. N. S., Arsad, N., Hussain, H., Zaki, W. M. D. W., \& Aziz, N. A. (2012). The Influence of Socio-Economic Status among Matriculation Students in Selecting University and Undergraduate Program. Procedia - Social and Behavioral Sciences, 56(2005), 134-140. https://doi.org/10.1016/j.sbspro.2012.09.640

Moreno, A. (2012). The Transition to Adulthood in Spain in a Comparative Perspective: The Incidence of Structural Factors. Young, 20(1), 19-48. https://doi.org/10.1177/110330881102000102

Newman, L. a. (2009). Do socioeconomic differences in family size reflect cultural differences in confidence and social support for parenting? Population Research and Policy Review, 28(5), 661-691. https://doi.org/10.1007/s11113-008-9124-3

Onatsu-Arvilommi, T. P., \& Nurmi, J.-E. (1997). Family background and problems at school and in society: The role of family composition, emotional atmosphere and parental education. European Journal of Psychology of Education, 12(3), 315-330. https://doi.org/10.1007/BF03172879

Panorama, M., \& Jdaitawi, T. (2011). Relationship between Emotional Intelligence and Work-Family Conflict of University Staff in Indonesia. In Proceeding of the International Conference on Social Science, Economics and Art 2011 (pp. 272-277).

Parsa, P., Panah, M. A., Parsa, N., \& Ghaleiha, A. (2014). The Relationship between Perceived Inter-parental Conflict and Academic Adjustment in First Year Students' Hamadan, Iran. Procedia - Social and Behavioral Sciences, 152, 720-724. https://doi.org/10.1016/j.sbspro.2014.09.310

Pettit, G. S., Yu, T., Dodge, K. a., \& Bates, J. E. (2009). A Developmental Process Analysis of Cross Generational Continuity in Educational Attainment. Merrill-Palmer Quarterly, 55(3), 250-284. https://doi.org/10.1353/mpq.0.0022

Régner, I., Loose, F., \& Dumas, F. (2009). Students' perceptions of parental and teacher academic involvement: Consequences on achievement goals. European Journal of Psychology of Education, 24(2), 263-277. https://doi.org/10.1007/BF03173016

Sáinz, M., Pálmen, R., \& García-Cuesta, S. (2012). Parental and Secondary School Teachers' Perceptions of ICT Professionals, Gender Differences and their Role in the Choice of Studies. Sex Roles, 66(3-4), 235-249. https://doi.org/10.1007/s11199-011-0055-9

Salami, S. O. (2004). A path model to examine factors influencing career orientations of school-going adolescents in Nigeria. International Journal for the Advancement of Counselling, 26(1), 79-94. https://doi.org/10.1023/B:ADCO.0000021551.61838.0 
Sallee, M. W. (2013). Gender Norms and Institutional Culture: The Family-Friendly Versus the Mother-Friendly University. Journal of Higher Education, 84(3), 363-396. https://doi.org/10.1353/jhe.2013.0017

Schildberg-Hoerisch, H. (2011). Does parental employment affect children's educational attainment? Economics of Education Review, 30(6), 1456-1467. https://doi.org/10.1016/j.econedurev.2011.07.013

Sheridan, J., Brennan, P. F., Carnes, M., \& Handelsman, J. (2006). Discovering directions for change in higher education through the experiences of senior women faculty. Journal of Technology Transfer, 31(3), 387-396. https://doi.org/10.1007/s10961-006-7210-4

Smith, B., Ray, G. E., Stefurak, T., \& Zachar, P. a. (2007). College student evaluations of parent-child $\begin{array}{lllll}\text { disciplinary situations. Journal of Family Violence, 22(8), 757-767. } & \text {. }\end{array}$ https://doi.org/10.1007/s10896-007-9123-x

Smith, L. (2011). Experiential "hot" knowledge and its influence on low-SES students' capacities to aspire to higher education. Critical Studies in Education, 52(May 2015), 165-177. https://doi.org/10.1080/17508487.2011.572829

Shokoohi, R., Hanif, N. R., \& Dali, M. (2012). Influence of the Socio-Economic Factors on Children's School Travel. Procedia - Social and Behavioral Sciences, 50(July), 135-147. https://doi.org/10.1016/j.sbspro.2012.08.022

Sy, S. R., \& Brittian, A. (2008). The impact of family obligations on young women's decisions during the transition to college: A comparison of Latina, European American, and Asian American students. Sex Roles, 58(9-10), 729-737. https://doi.org/10.1007/s11199-007-9385-z

Sydney, W. (2011). Effectiveness of Developing Pathways to University Entry for Low Socioeconomic Status Students, $1-6$.

Taylor, R. D. (2015). Kin Social Undermining, Adjustment and Family Relations Among Low-Income African American Mothers and Adolescents: Moderating Effects of Kin Social Support. Journal of Child and Family Studies, 24(5), 1271-1284. https://doi.org/10.1007/s10826-014-9935-2

Teodor, M. (2012). The Influence of Socio-Economic Status on School Performance. Romanian Journal of Experimental Applied Psychology, 3(2), 21-28.

Tieben, N., \& Wolbers, M. H. J. (2010). Transitions to post-secondary and tertiary education in the Netherlands: A trend analysis of unconditional and conditional socio-economic background effects. Higher Education, 60(1), 85-100. https://doi.org/10.1007/s10734-009-9289-7

Utter, J., Denny, S., Dixon, R., Ameratunga, S., \& Teevale, T. (2012). Family support and weight-loss strategies among adolescents reporting sustained weight loss. Public Health Nutrition, 16(3), 1-6. https://doi.org/10.1017/S1368980012002820

Veas, A., Gilar, R., \& Miñano, P. (2016). The Influence of Gender, Intellectual Ability, Academic Self-Concept, Self-Regulation, Learning Strategies, Popularity and Parent Involvement in Early Adolescence.

Wang, Y., Liang, H., Tussing, L., Braunschweig, C., Caballero, B., \& Flay, B. (2007). Obesity and related risk factors among low socio-economic status minority students in Chicago. Public Health Nutrition, 10(9), 927-938. https://doi.org/10.1017/S1368980007658005

Weer, C. H., Greenhaus, J. H., Colakoglu, S. N., \& Foley, S. (2006). The role of maternal employment, role-altering strategies, and gender in college students' expectations of work-family conflict. Sex Roles, 55(7-8), 535-544. https://doi.org/10.1007/s11199-006-9107-y

Wright, R. J., Bean, A. G.,(1974). The Influence of Socioeconomic Status on the Predictability of College Performance. Journal of educational measurement, 11(4), 277-284.

Zakeri, H., Esfahani, B. N., \& Razmjoee, M. (2013). Parenting Styles and Academic Procrastination. Procedia Social and Behavioral Sciences, 84, 57-60. https://doi.org/10.1016/j.sbspro.2013.06.509

\section{Copyrights}

Copyright for this article is retained by the author(s), with first publication rights granted to the journal.

This is an open-access article distributed under the terms and conditions of the Creative Commons Attribution license (http://creativecommons.org/licenses/by/4.0/). 